\title{
Impact of Personal Recruitment on Organisational Development: A Survey of Selected Nigerian Workplace
}

\author{
Olatunji Eniola Sule (MNIM) \\ Department of Business and Finance, Crescent University, Abeokuta, Ogun State, Nigeria \\ Tel: 234-80-6342-8299, 234-80-5603-7734Ｅ-mail: olasem2005@yahoo.com \\ Mrs. Ugoji I. Elizabeth (P.hD) \\ Department of Secretarial Administration, Rivers State University of Science \& Technology \\ Port Harcourt, Rivers State, Nigeria \\ Tel: 234-80-3316-7243Ｅ-mail: bettyugoji@gmail.com
}

Received: October 21, 2012

Accepted: February 14, $2013 \quad$ Online Published: March 14, 2013

doi:10.5430/ijba.v4n2p79

URL: http://dx.doi.org/10.5430/ijba.v4n2p79

\begin{abstract}
The purpose of this study is to examine the processes through which personnel are recruited into organisation and the impacts of the personnel recruitment on the organisational development. Six research questions and two hypotheses were postulated to find solutions to the problems of the study. One hundred and fifty senior personnel formed the sample size from six organisations. A self-designed instrument labeled Personnel Recruitment Process Impact Questionnaire (PEREPRIQ) containing five sections was used in the collection of data. The findings of the study revealed certain recruitment procedures adopted in organisations. It also revealed that the recruitment procedures used in the organisation influence personnel behaviour and performance to a large extent. It further established those factors militating against recruitment processes in organisations as well as its consequences on the personnel and organisational development. Based on the findings, the following recommendations were proffered that recruitment processes and procedures must be developed which all applicants must pass through; that all applicants must all be treated equally, and that what constitute qualification and merit must be well spelt out to include applicant ability to "deliver" and not just 'paper' qualification.
\end{abstract}

Keywords: African, Recruitment, Relatively big organisations, Organisational development

\section{Introduction}

\subsection{Background of the Study}

As enterprise grows in size, the tendency has been for the work of management to be subdivided, initially into such primary functions as manufacturing, selling and possibly, purchasing, but later into functional areas like accounting, marketing, finance, personnel management and so on. Work, generally, has become more specialised, therefore greater knowledge is now required by those selecting employees for jobs.

Furthermore, recruitment which is the securing a supply of possible candidates for the jobs in an organisation is the first stage in the process of employment which involves determining the required number of personnel required, the kind and type of personnel needed, what kind of employment to offer (contractual or pensionable employment), determine where such personnel are available and find the means of attracting them towards the organisation before starting the process of selection. This is the most common process of recruiting in organisations but nowadays things are not done this way. For instance, just because an officer in an organisation wants a particular person employed in his/her organisation, vacancy can be created; by that there is no need to determine the kind of person needed, where such personnel are available and means of attracting them towards the organisation.

However, if the African man is observed in his self-employed concern, he is very hardworking, but when he is in wage-earning (industrial or public service) employment, his attitude to work generally falls far below that of his counterparts in more advanced countries (Ahiauzu, 1999). Though historical records show that wage-earning employment was non-existent in pre-colonial Africa (Yesufu, 1962; Ananaba, 1969; Fapohunda, 1977). Working for 
another, even for payment was associated with slavery and looked upon as degrading, by contrast with the independent status of a farmer or self-employed entrepreneur. As at the time the colonial masters came into Africa to take charge of governmental affairs in their colonized territories, much positive consideration were not given to the negative traditional attitude of our fore-fathers to wage-employment. Perhaps, a positive consideration of the traditional system at that time would have made it possible for the administrators to adopt recruitment methods that would have aimed at attracting the Africans voluntarily into accepting wage-employment.

Instead, the use of force were adopted by the colonial administrators and as such very many Africans still see wage-employment as forced labour and "white-man's work". The psychological effect of the forced labour system still lingers on from generation to generation. For instance, Ocho (1984, p. 35) while commenting on the effect on the notion of 'white-man's work' on the work attitude of Africans remarked that among the Ibo tribe of South-East Nigeria the "Olu Oyibo" (white man's work) notion was greatly believed to be one of the major causes of people's poor attitude to work especially among civil servants and other public workers; so much that between 1967 and 1970, the then Administrator of the area decided to launch a public campaign against it. He tried to change the notion of 'Olu Oyibo' to 'Olu obodo' (community work). But despite that, there is no significant change in the peoples' attitude and perception of wage employment. Today, we found most people from Ibo tribe in trading activities which suggest that the 'Olu Oyibo' attitude is still deeply rooted in this present generation of the Ibo tribe of South-East Nigeria. But due to our mismanaged economy, most individuals want to start life with wage-earned employment and after few years move into self-employment.

But that notwithstanding, personnel is one of the four- $M s$ that makes an organisation or a firm. The four-Ms, means money, man, machinery and materials; in fact, if it is arranged in the order of priority, Man should have come much more earlier than the rest of the Ms. Technology is produced by man and as such, technology of any kind, starts, advances and ends its existence in human mind. Ahiauzu, (1999:46) clarified it by saying that "what we see as tools, machines, production methods and techniques, which constitute hard and soft technologies are merely manifestation of what had earlier existed in the minds of men, in the form of ideas, that had become crystallized from human thoughts".

How then can organisation develops if the factors that constitute the major and vital sector are not the right and best caliber of people? This is why the researcher sees the issue of personnel recruitment into organisations as very paramount to the continuous existence of an organisation particularly the middle class personnel. If an organisation fails, it is the personnel that make up the organisation that failed collectively and more importantly the recruitment process of the organisation. Inversely, the survival of any organisation depends largely on the personnel; for instance, the demise of Enron Company of United Kingdom was due largely to the personnel. However, not the personnel alone, but the effect of the way and manner the personnel were recruited like the then Enron Chief Executive Officer (CEO) Jeff Skilling who was solely handpicked by the founder of Enron Mr. Ken Lay.

Most of the time, businesses fail and sometime die a natural death and it is blamed on the management. Which management? the financial, personnel, marketing, sales, administration/secretarial, accounting, strategic/policy management or what? There should be a specific aspect of management that should carry the lion share of the blame and the researcher thinks nobody has ever given it a thought that most problems that leads to the failure of organisations arise mostly within the recruitment processes of each and every organisation. The researcher shall, therefore, want to ascertain how the Africanism in us in this part of the world affects recruitment processes in our workplace and consequently, the overall performance of the organisation. It must be noted that the failure of every organisation cannot be settled at the door step of personnel management experts alone but what the researcher is trying to show can only be well understood if the study is followed to the conclusion.

It is pertinent to point out that influencing the processes of recruitment often give room for 'favouritism and god-fatherism'. In fact, things will never be done properly no matter the laid down rules. In such cases, employee's loyalty will only be to the god-father and not to the organisation and thus can adversely affect organisational development.

\subsection{Problem Statement}

There is little or nothing wrong in the normal processes of personnel recruitment but the mode and pattern of following the processes of personnel recruitment is what creates a problem in workplaces. Most organisations refuse to adhere strictly to the procedure of personnel recruitment while some adhere to it but allow a lot of influences to affect their personnel recruitment activities. This tends to affect individual worker performance and the organisational development. 
In Fortune Magazine of February, 1976 (pp. 88-90), James Sinegal, a one time Chief Executive Officer, Costco Warehouse said that "If you hire good people, give them good jobs and pay them good wages, generally something good is going to happen". In the same vein, Cumming (1978) has argued that the management of human resources is "concerned with obtaining the best staff for an organisation, and having got them, looking after them so that they will stay and give of their best to their jobs". Here the emphasis is on getting the best staff for an organisation before looking after them. But today, do most organisations care about getting the best staff? Is it not just getting-in whether through the "window", "front door" or the "back door"? Is it proper for organisation to just recruit without due care and later look after them? Organisation need to know that animalistic nature in man can only be modified and not changed completely.

Therefore, organisations incur more cost in the name of motivating and training. Encounter much inefficiency and ineffectiveness from such personnel, increase labour turnover and finally, drastic reduction in the organisational development.

Specifically, the problem of the study boarders on ascertaining the recruitment procedures employed by organisation; determine the extent to which such recruitment process influence workers behaviour and productivity; identify factors that militate against recruitment processes in organisation; ascertain whether recruitment process has any significant influence on organisational development; and ascertain whether communities demands influence personnel recruitment processes.

\subsection{Purpose of the Study}

The purpose of this study is to examine the processes through which personnel is recruited into organisations and the resultant effect of such on the organisational development. To achieve this, the study will aim at:

i) identifying the procedures used in staff recruitment;

ii) determine the extent to which the recruitment procedure influence workers behaviour, productivity and performance;

iii) identify factors that militate against effective recruitment processes in organisations;

iv) determine whether there is any significant relationship between recruitment processes and organisational development;

i) ascertain whether recruitment process has any significant influence with organisational development;

ii) ascertain the consequences of community pressures on staff recruitment and organisational development;

v) to proffer suggestions as to improving the recruitment of personnel.

\subsection{Research Questions}

To achieve the purpose of the study the following research questions will be addressed:

(i) What are the procedures adopted in recruitment of personnel?

(ii) To what extent does the recruitment procedure used in the organisation influence personnel behaviour?

(iii) To what extent does the recruitment procedure used in the organisation influence personnel performance?

(iv) To what extent do communities influence personnel recruitment in organisation?

(v) What factors militate against recruitment processes in the organisation?

(vi) What are the likely effects of such community recruitment on organisational development?

\subsection{Research Hypotheses}

To pilot the study to a conclusive end, the following hypotheses will be tested:

$\mathrm{Ho}_{1} \quad$ There is no significant difference in the ranks of male and female perception of personnel recruitment process and personnel performance.

$\mathrm{Ho}_{2}$ There is no significant difference in the ranks of male and female perception of personnel recruitment process and organisational development.

\subsection{Significance of the Study}

The study on the impact of personnel recruitment on organisational development is very important and useful to the organisation's management, recruitment officers and practitioners, employees, government and the influencing agents. The study is to expose the impact the recruitment procedures will have on the performance of each and every personnel. 
The findings would be of great significance to organisations, as it would give room for comparison of recruitment processes adopted by organisation.

The study is to help organisation in terms of attainment of organisational goals, increasing the efficiency, adaptability and achieving long-term results. The study helps the employees to have awareness and clear idea about the various recruitment policies and procedures.

\subsection{Limitation and Delimitation of the Study}

The study examined the recruitment processes used in organisations; ascertained the relationship between the recruitment processes used and personnel performance in particular and the organisational development. The organisations studied include SCOA Motors, Port Harcourt Refinery Company Limited, Eleme Petrochemical Company Limited, Atlas Cement Company Limited, MTN Communications Limited and B. J. Oil and Gas Services Limited; all in Rivers State, Nigeria.

The study concentrated mainly on the middle level personnel of the organisations studied. The study concerned itself with the impacts of personnel recruitment on organisational development with a focus on relatively big organisations.

The researcher had a tough time administering the research instrument (questionnaire) as well as the retrieval of the questionnaire. This is due largely to the general presumption of Nigerians about research work that it is a futile effort and will not have any impact on anything and that the findings of such research work cannot see the light of the day; as such it is considered a time wasting exercise. By so doing, questions are not faithfully answered by most of the respondents.

In addition, due to what this research work focused on, many of the respondents are very scared of responding and even where they do some of the questions were avoided. This is due to the fact that many Nigerian personnel came into work through one influence or the other and also the fear of speaking against the power that be in the organisation. Another fear exercised by some of the respondents is the fear of exposing the secret of the organisation recruitment processes and procedures to the public. All these, therefore, had certain impact on the responses as well as the generality of the study findings.

\section{Literature Review}

\subsection{Introduction}

This chapter focused on the conceptual framework upon which the work is based and a review of literature related to the study. Although, much work has not been done in the area of the impact of personnel recruitment on organisational development as revealed by the search of literature. There were, however, some related studies to the present study.

The review, therefore, focused on the following areas:
i) Conceptual framework;
ii) Factors that militate against effective recruitment processes;
iii) Procedures for personnel recruitment;
iv) Relationship between recruitment processes and organisational development;
v) Consequences of influence on recruitment processes and organisational development.

\subsection{Conceptual Framework}

The conceptual framework of this study is based on the outcome of study carried out by Fubara, B. A. in 1984 tagged "Power Behind the veil in Public Enterprises in Developing Countries with a case study of Policy Formulation Pakistan Administration". Fubara study was based on state owned enterprises in developing countries. According to Fubara, such organisations dominate developing economies and this compels inquiry into their efficiency and effectiveness. In probing into the strategic decision processes behind the often dismal-performance of these organisations, Fubara found that decision processes are influenced by power games from within and outside the organisations. It was convincingly established that prominent among the decisions been influenced are the recruitment decisions. When recruitment decisions are influenced; it now mean that recruitment processes and procedures are averted which account for the dismal performance of these organisations.

Fubara (1984) came up with three vital conclusions. First, the recruitment and appointment of Chief Executive Officers and others are influenced by powers aside the organisation, primarily political powers. This raises questions of legitimacy of purpose and objective of the organisation. Second, arising from the open knowledge of political appointments of the top executive rather than merit-based appointments, senior managers and workers alike tend to 
influence corporate decisions through their own power connections. Thirdly, this power game negatively influences the already misconceived corporate shared values.

Based on the first and second assertions in Fubara (1984), it is clearly revealed that many problems arise due to non-compliance with an organisation recruitment procedures and policies. This is what this present study tries to establish but by widening the scope of the organisation to include private sectors. Therefore, Fubara 'Power Behind the Veil' is related to the present study as it shows the impacts of recruitment processes on state owned organisational development.

Apparently, not much work appears to have been done in this direction apart from Fubara, 'Power Behind the Veil'; especially in terms of subjecting recruitment processes to a thorough scrutiny. Again, Fubara's Power Behind the Veil was not directly studying the impact of non-compliance with recruitment processes on the organisational effectiveness and development. But instead, it was trying to show how the kingmakers, head of government, relevant government agencies, ministries, board of directors, and so on influence decision making through what Fubara called "Decisioning through Power Plays". Again, Fubara (1984) inquired into efficiency and effectiveness of state owned enterprises and found out that recruitment through certain influences rather than merit-based form the biggest obstacle to efficiency and effectiveness of enterprises studied. Despite all these, the study - Power Behind the Veil is still a very promising one, very concise and in tune with day-to-day events in our society.

Furthermore, recruitment policies and procedures are usually designed in line with the organisation climates based on different philosophies thereby leading to different behaviour expectations. This presupposes that if the recruitment policies and procedures are not followed the organisation behaviour expectations would not be met. Cole (2002) made it known that personnel management implies emphasis on implementation of procedures, including recruitment procedures. Therefore, Fubara concept of Power Behind the Veil will be the bedrock of this present study; since it is very clear that the importance of using efficient and effective procedures for recruitment can hardly be overemphasis from the foregoing discourse. If organisations were able to find and employ staff through the organisation recruitment processes most staff would consistently fulfil their roles and would be capable of taking on increased responsibilities. Such personnel would be immeasurably better placed to deal with the opportunities and threats arising from their operating environment than competitors who are always struggling to build and maintain their workforce (Cole. 2002). For better analyses, a critical look at the factors militating against effective recruitment processes must be done.

\subsection{Factors Militating against Effective Recruitment Processes}

Performing the function of recruitment, that is, increasing the selection ratio is not as easy as it seems to be. This is because of the hurdles created by those factors described by Rao and Rao (1990:169) as internal and external factors, which militate against effective recruitment exercise in an organisation. These factors give room for jumping the recruitment processes and/or not carrying out recruitment exercise based on equity, fairness and thorough hearing.

Fubara, (1984) described those factors as power game and pointed at the kingmakers, head of government, relevant ministries, board of directors, senior managers, employees and chief executives. Rao and Rao (1990) said those factors include the organisational policy regarding filling up of certain percentage of vacancies by internal candidates, local candidates (the son-of-the-soil), influence of trade unions, government regulations regarding reservations of certain number of vacancies to candidates based on community, region, religion, sex and recommendations as well as outright nepotism.

For better understanding, the factors will be discuss under the heading - Host Community, Power behind the Veil, Government Regulation, Union and Staff Members influencing factors.

\subsubsection{Host Community Influencing Factor}

This is the most rampant and popular today. It is a situation where the community where organisation is located tries to impose certain employees on such organisation for immediate employment. Such employees are usually not allowed to pass through any recruitment process. In some cases, they do not even submit application for consideration before the issuance of letter of employment. Rather the Youth Leader in that community or the Community Development Committee (CDC) Chairman will only compile names of the would-be employees and submit to such organisation not even for consideration but for immediate employment. This is superimposition of personnel on organisation, which attract lawlessness and undedicated attitude to such organisation. Investigation revealed that most staff employed through this system hardly come to work and sometime have their names on the pay-list of two or more organisation. Such organisation always struggle to build and maintain their workforce (Cole, 2002). The son-of-the-soil' factor has become conveniently handy to leadership appointment, local pressures and social as well as political parochialism (Afolabi, 1988:7). 


\subsubsection{Power behind the Veil Influencing Factor}

These are influencing powers that are not too conspicuous around an organisation. These are influences coming from the kingmakers, relevant ministries or agencies, head of government and board of directors as in public enterprises (Fubara, 1984). But in private enterprises you have all the mentioned above influences as well as from foreign partner, financier, and shareholders, hiding under the pretence of protecting their interest in organisation, super-impose personnel on organisation as such recruitment process is set aside to give way for improper recruitment.

Ugoji (1995:54) while commenting on the appointment of Vice Chancellors in the Universities said that "the reality of the matter is that influential personalities in the society bring pressures to bear on the visitor". Ogunsanwo (1983) also confirmed that the appointments of Vice Chancellors are even done outside the university to where they belong.

\subsubsection{Union and Staff Members Influencing Factor}

Organisation's Staff Union which is an organisation of workers whose principal purposes include regulation of relations with employers, or a federation of such organisation (Trade Union and Labour Relations Act, 1974). We found staff union turning to pressure group in our organisations and thereby assuming certain power and role though unofficially. Union tends to exercise such power over and above the recruitment processes of organisations. The Trade Union and Labour Relations Act allow trade dispute in cases connected with "engagement or non-engagement, or termination or suspension of employment, or the duties of employment, of one or more workers.

Staff members influence personnel recruitment processes through the use of the instrument of nepotism, recommendation from friends and associates or membership of the same religious association. This is rampant in sole entrepreneur business where family members and relations are brought into the organisation without the proper recruitment processes. As such, Rao and Rao, 1990 said "the management is not free to find out the best among the applicants. Have you ever heard of the PRO quota for public relations. Candidates with short notes stating magic words, 'this is my candidate' (Ugoji 1995:65).

\subsubsection{Government Regulation Influencing Factor}

From time to time government does come up with statutory laws to regulate recruitment of employees in both private and public enterprise. We have many of such law both at State and Federal level of government. For instance, Rivers State House of Assembly enacted an edict called Employment Edict of Year, 2000. The edict made it mandatory on all enterprises operating in the State to have at least 40 percent of their workforce as the indigene of Rivers State. Moreso, the lower level staff of all enterprises within the State must all be indigene of Rivers State.

At the Federal level we have the use of quota system in selecting candidates. That is, all the six geo-political area must be well represented. Odikpo (1988) submitted that government often impose an outsider of its choice as Vice chancellor while Popoola (1988) said the appointment are based on quota, others on state, ethnicity or even sectional rivalries. In other words, recruitment exercise cannot be based on merit but subverted with government intervention and regulations. Sequel to this, 'god-fatherism' and 'quotarism' over-shadow the personnel recruitment processes, using the terminology of Ugoji (1995:65).

\subsection{Procedures for Personnel Recruitment}

In recruiting personnel into organisation varying methods are used to discover significant information about an applicant, which can then be compared with the job specification. Flippo (1984) affirmed that there is no standard procedure adopted by all firms; but organisations still carry out recruitment. Nevertheless, the specific step used is the same sequence. The procedure varies with the size of the company, the type of job to be filled, the philosophy of the personnel management and the external forces.

In order to initiate the procedure for recruitment, we must satisfy the three preliminary requirements depicted in Figure 1. First, there must be the authority to recruit, which comes from the employment requisition, as development through analysis of the work load and work force. Secondly, we must have a standard of personnel with which we can compare prospective employees. This is represented by the job specification, as developed through the analysis. And finally, we must have job applicants from whom we can select the persons to be recruited. A planned recruitment programme provides us with these applicants.

$<$ Insert Figure 1 Here $>$

The recruitment procedure is essentially a series of methods of securing pertinent information about the applicant. At each step we learn more about the prospect. The information obtained can then be compared with the job specification and the standard of personnel. If the applicant qualifies, he or she advances to the next step. Thus, job specifications 
and the job applicant are present at each step in the recruitment procedure. The step constitutes the means by which the applicant's qualifications can be compared with the minimum requirements established in the job specification.

Evaluating the abilities of a human being is an extremely difficult task. There are no easy shortcuts, and the recruitment procedures used by the more advanced firms are long and complicated. This fact has not entirely prevented the use of various techniques of quick appraisal, some of which are well organised and can be called "pseudo sciences". Among such practices are phrenology (skull protrusions), physiognomy (facial features), astrology (birth date), pigmentation (blonde-brunette), and graphology (handwriting) (Flippo, 1984).

Most people do not consciously practice any of these pseudo sciences, but many have favourite techniques of their own, judging by such things as how a person shakes hands, whether one looks you in the eye, and how one holds a pen. Again, we must emphasise that there is no easy shortcut to the accurate evaluation of a human being under any circumstances.

In evaluating job seekers, there must be a personnel specification. Personnel specification or candidate profile as it is sometimes called is to make explicit the attributes that are sought in candidates for the job in question. Thus, the personnel specification becomes a summary of the most important knowledge, skills and personal characteristics required by the successful candidate in order to be able to carry out the job to an acceptable standard of performance. The personnel specifications depends, for its relevance, on the nature and scope of the job, as described in the job description, amplified where necessary by comments from the manager concerned. Naturally, the nature of the job will determine the type and level of knowledge and skills required, but the job will be performed in a particular social context, and so it is important to have the manager's view as to the sort of personal qualities that would permit the newcomer to fit into the team (Cole, 2002).

Drawing up adequate specifications is therefore not easy. As Fraser (1978) puts it

“... each human being is unique and can only be understood as a complete entity. Ill-conceived attempts to force him into classifications usually lead to essential elements being either concealed or missed out altogether. But when trying to select from among a group of candidates, we want to be able to compare one with another. Thus we must describe each in terms which have a common application".

Fortunately, there have been several useful attempts to draw up a practicable if not ideal classification of personal attributes for the purposes of placement. There are many classifications but two are most popular; they are the seven-point plan and five-point grading.

The seven-point plan was devised by Rodger (1950), and has proved to be the most popular model for personnel specifications. The seven points are:

1) Physical Make-up - what is required in terms of health, strength, energy and personal appearance?

2) Attainments - what education, training and experience is required?

3) General Intelligence - What does the job require in terms of thinking and mental effort?

4) Special Aptitudes - what kind of skills need to be exercised in the job?

5) Interests - what personal interest could be relevant to the performance of the job?

6) Disposition - what kind of personality are we looking for?

7) Circumstances - are there any special circumstances that the job requires of candidates?

With these seven-point plans, it is possible to categorize the candidate specifications under Essential and Desirable features. The relationship between the essential and desirable features is a factor $(a)$ of the job itself, and $(b)$ of the labour market. If a job requires specific knowledge or skills at a particular level to ensure that new recruits will be able to fulfil their duties acceptably, then Cole (2002) said these levels must be stated as essential.

If the job only requires commonsense levels of know-how, then the specification can be written in broad terms with few essential features. However, the recruitment situation is inevitably linked to the state of the labour market. If labour of a particular kind is plentiful, then specifications can be made more exclusive than if there is a shortage of the relevant labour, in which case employers loosen their personal specifications, so as to ensure that at least some candidates will be caught in the net.

In recent years, the labour market has swung back in favour of employers. Now the problem is not so much of attracting candidates, but in deciding how best to select them (Cole, 2002). Lewis (1985) sees the problem in these terms: "In practical terms, attracting applicants is less of an issue, but administration and deciding whom to offer employment to 
are more difficult with large numbers". The present situation encourages employers to set tight specifications for all but the scarcest of jobs. Even with this strategy employers are being faced with large numbers of well-qualified candidates, and so recruitment processes become more time-consuming and problematic.

Another well-known classification of human characteristic for personnel recruitment is Fraser's five-point grading. First, impact on others which embraces Rodger's physical make-up and also aspects such as dress, speech, manner and reactions. Fraser emphasises "the importance of looking at an individual quite objectively from this point of view". Second, acquired knowledge or qualifications which deals with general education, work experience and training, and is similar to Rodger's Attainments category. Third, innate abilities or 'brains' referring to the individual's ability to exercise his or her intelligence in a range of situations, and is especially applicable in cases where the individual has few formal qualifications. Fraser suggests that 'from this point of view, we are perhaps mainly concerned with his potentialities'. Fourth, motivation which is concerned with the 'goal -directed' aspect of human personality. Fraser sees this more in terms of how the individual has achieved his or her personal needs and ambitions, rather than with trying to identify these needs. Lastly, adjustment which concerns the emotional status of the individual stability, maturity, ability to cope with stress, for example. Fraser suggests here that the qualities under discussion are basically aspects of 'the individual's reaction to pressures'.

Fraser's model, like Rodger's does make an important contribution to the recruitment and selection process in organisations. It provides a practical framework for enabling selectors to make reasonably consistent comparisons between one candidate and another. The important point here is that the organisation is at least trying to introduce a greater element of predictability and control into an aspect of personnel management in which personal judgement and individual prejudice blend rather uneasily together in a situation where objective information may be in short supply.

Probing further, Flippo (1984) gave the following as an example of a popular processes:

1) Initial or preliminary interview

2) Application blank or blanks

3) Check of references

4) Psychological tests

5) Employment interview

6) Approval by the supervisor

7) Physical examination

8) Induction or orientation

Cole (2002) gave the key stages in the recruitment processes to include the following:

1) Sifting through application forms or Curriculum Vitaes (CVs)

2) Drawing up a shortlist of candidates

3) Inviting these candidates for interview

4) Conducting interviews (supported by tests where appropriate)

5) Making a decision about choice of candidates

6) Making an attractive offer and confirming it

7) Writing to unsuccessful candidates

8) Notifying appropriate managers of decisions.

Rao and Rao (1990) gave certain steps, which was referred to as scientific recruitment and selection processes to include:

1) Job analysis

2) Scouting

3) Application form

4) Written examination

5) Preliminary interview

6) Group discussion 
7) Tests which entails intelligence, aptitude, achievement, interest, personality, situational, judgement and projective tests.

8) Final interview

9) Medical examination

10) Reference checks

11) Final decision by the Line Manager

12) Employment.

DeCenzo and Robbins (2003) gave their own steps as follows:

1) Initial screening interview

2) Completion of the application form

3) Employment tests

4) Comprehensive interview

5) Background investigation

6) Physical examination

7) Final employment decision.

All the researchers (Flippo, 1984; Rao and Rao, 1990; Cole, 2002; DeCenzo and Robbins, 2003) agreed that there is no standard recruitment process that can be followed by all the organisations in all the areas. But organisations may follow different recruitment techniques or processes depending upon the size of the company, nature of the business, kind and number of persons to be employed, government regulations to be followed and the philosophy of the personnel management. This gave way to what we see nowadays that organisations just choose to recruit anyhow not following any particular processes in recruiting personnel - Influenced recruitment - some of which are highlighted.

In the recruitment procedure varying processes are used to discover significant information about an applicant. Different processes were posited by different researchers but looking through all, there are some salient features derived from other studies. The salient features are the application details, interview and selection tests. The relationship between these features can be shown diagrammatically as in Figure 2.

$<$ Insert Figure 2 Here $>$

\subsection{Relationship between Recruitment Processes and Organisational Development}

The existing relationship between recruitment processes and organisational development can be likened to the relationship between the raw materials with which a product is to be produced and the final output. We all realised that no matter the technological input into a bad raw material the final product cannot be something to talk about. Since we cannot put something on nothing, likewise we cannot expect a good organisational development without a better recruitment processes.

Recruitment (human resources) along with financial and material resources, contribute to the production of goods and services in an organisation. Also, physical and monetary resources by themselves cannot improve efficiency or contribute to an increased rate of return on investment. It is through the combined and concerted efforts of people that monetary or material resources are harnessed to achieve organisational goals and development (Rao and Rao, 1990).

Fubara (1984) established a solid and strong relationship between recruitment processes and organisational development when he concluded that the often dismal performance of public enterprises was due largely to the selections and appointments of officers, senior managers and workers alike. Fubara (1984) made it clear that the recruitment are usually political and not merit-based; and the scenario of coming into organisation through certain influence depict how meritocracy is relegated to the background for mediocrity (Ugoji 1995:65).

With proper recruitment processes, there will be job satisfaction which Mathis and Jackson (1997) said is a positive emotional state, resulting from evaluating one's job experiences. With job satisfaction motivating instrument becomes a secondary issue to employees and there will be a better performance. Where there is better performance, cost will be minimised, profit invariably will be maximised and finally, organisational goal and development attained.

Odukoya (2004:43) said management should make solidified plans and answers that individuals are rightly linked to their jobs for organisational success. Mathis and Jackson (1997) noted that in a competitive environment, many 
organisations do not succeed over the long term. Those that succeed need on-going contributions from the human resources in the organisation to become successful and continue their success over time.

Employees who are the human resources must be well managed by the organisation for effectiveness, efficiency and high productivity. But effective and proper employees' management starts from the recruitment by getting the best candidate for the job. This is to enable the employee to stay and give their best to the organisation; that is contributing to the organisational development. Mathis and Jackson (1997) said the activities that focus on human resources management can provide a direct contribution to organisation performance. Such contribution can be positive or negative, depending on the effectiveness of employees and the implementation of the human resources policies and procedures.

Again, recruitment processes and procedures determine organisational health, which could be determined by looking into employees' contribution to organisational goals and the employee job satisfaction. Employee satisfaction could be understood by labour turnover, absenteeism, commitment and the like. Low rate of absenteeism and high rate of employee commitment indicates employee-satisfaction about the job and the organisation.

Good recruitment processes help in attracting and retaining the best people in the organisation. Appropriate recruitment activities identify the best people for available jobs and make sure they are placed in suitable positions (Roa and Rao 1990). When the best people are identified and placed on the job they help achieve organisational goal by staying and giving out their best to the organisation. In the same vein, good recruitment practice can motivate organisational members to do outstanding work. Therefore, having established the relationship between recruitment processes and organisational development; it is pertinent to now consider some of the consequences of influences on recruitment processes and organisational development.

\subsection{Consequences of Influences on Recruitment Processes and Organisational Development}

Recruitment processes suffer much influence from the host community, power behind the veil, union and staff members as well as from government regulations. All these influences have many consequences on the recruitment processes as well as on the organisational development. Though, there might be few positive consequences it will be very insignificant compared with negative consequences.

Some of the consequences include relegation of meritocracy to the background, disaffection and disharmony amongst staff members, hypocrisy and disloyalties, absenteeism, huge loss of labour hour, high cost of production, problem of the organisation to cope with opportunities and threats. Others are low productivity, high labour turnover, high cost of manpower development and finally, dismal performance of organisation.

Those that suffer the consequences directly or indirectly include individual/employee, organisation and the society. For instance, brilliant materials (applicants) are slaughtered on the alter of 'god-fatherism' and 'quotarism' with the scenario of coming into organisation through certain influence which depict how meritocracy is relegated to the background for mediocrity (Ugoji 1995:65).

Again, employees imposed on organisations rather than merit-based appointment are always 'stranger' in such environment "since the new appointee often times have little or no knowledge of the environment, the people, nuances and circumstances" (Odikpo 1988:147). "Such imposition is an infringement on the laws ... as a result hypocrisy become entrenched within the system ..." Ugoji (1995:56). Also, employees that comes into organisation through certain influences are placed under pressures and they act according to the dictates of the influencing force that put them in position. Afolabi (1988:8) asserted that, "it becomes normal to seek to satisfy the powers that be"; that is, to satisfy the god-fathers and not the organisation".

Influences on recruitment processes "inject bad blood into the system culminating in tension generating crises that can engulf the system and threaten the peaceful tranquility, progress as well as the very existence of the system (Odikpo 1988:147). Invariably, disaffection and disharmony amongst staff members and colleagues becomes the order of the day; no more team work.

Cole 2002:172 said "if organisations are able to find and employ staff who consistently fulfil their roles and are capable of taking on increased responsibilities, they are immeasurably better placed to deal with the opportunities and threats arising from their operating environment than competitors who are always struggling to build and maintain their workforce". Ottih (2002) in trying to use systems approach as a way of measuring organisation effectiveness opined that one of the indicators of the system approach is the ability of the organisation to acquire scarce and valued resources - personnel, which cannot be acquire with influences on the recruitment processes and procedures. 
Avoiding unnecessary repetition, Fubara (1984) clearly show that influencing the selection and appointment of staff (especially middle level staff and above) raises questions of legitimacy of purpose and objectives of the organisation; the use of power connections to influence corporate decisions which finally, roll the organisation into dismal performance.

\section{Methodology}

\subsection{Research Design}

The research is a descriptive study based on survey design. Questionnaire was used to obtain relevant information from the respondents to examine the main dependent variables (personnel performance and organisational development), against the independent variable (personnel recruitment processes).

\subsection{Population of the Study}

The research population of this study consists of all middle level personnel of the relatively big organisations in Rivers State, Nigeria.

\subsection{Sample Size and Sampling Procedure}

The sampling procedure of non-probability of convenience or accidental sampling method was adopted due to accessibility of the respondents (sample). Therefore, a total of 150 respondents were selected to form the sample of the study.

\subsection{Instrument of the Study}

The study made use of a self-designed questionnaire tagged "Personnel Recruitment Processes Impact Questionnaire" (PEREPRIQ). Based on the literature reviewed, there is no relevant questionnaire available; as such PEREPRIQ was designed based on research problem.

The questionnaire was made up of five sections. Section 1 is about general background; section 2 deals with recruitment processes and procedures; section 3 is on the impacts of recruitment processes on workers performance and organisational development while section 4 deals with factors militating against proper recruitment processes and section 5 examined the consequences of influences on recruitment processes and organisational development.

Section 2, 3, 4 and 5 contained structured statements with four-response options based on Likert-type scale. These responses ranged from Strongly Agree (SA), Agree (A), Disagree (DA) to Strongly Disagree (SDA) and the respondents were required to indicate the extent to which they agree or disagree with the statements. The questions were assigned weight on a 4-point scale rated 1 to 4 as follows. Strongly Agree 4, Agree 3, Disagree 2 and Strongly Disagree 1 and the reverse is for negative statements.

The instrument (PEREPRIQ) was subjected to proper scrutiny of some experts in Management Sciences (Personnel) in Rivers State University of Science and Technology, Port Harcourt, Rivers State. Necessary corrections were made to upgrade the instrument before going to the field.

The instrument was subjected to validity and reliability test with the administration of the pre-test to twenty middle level management staff of Nigeria National Petroleum Corporation Staff School in Port Harcourt, Rivers State; though they did not form part of sample of the study.

Secondary data was collected mainly from reviewing the existing literatures relating to the issue under investigation and past personal experiences of the researcher.

Copies of the questionnaires were administered on 150 middle level management staff of six organisations, namely: SCOA Motors, Port Harcourt Refinery Company Limited, B. J. Oil and Gas Services Limited, Atlas Cement Company Limited, MTN Communications Limited and Eleme Petrochemical Company Limited.

\subsection{Methods of Data Analysis}

Data collected from respondents were handscored on scoring sheets for analysis. The Spearman Rank correlation Co-efficient was used to test the hypotheses postulated for the study. In addition, percentage, mean scores and standard deviation were also used in analyzing the data collected, and presented in tabular form.

To make decision on the tables, benchmark must be obtained by calculating the mean of the table mean score obtained by dividing the summation of the mean score by the number of the items analysed. In the same vein, the mean of the standard deviation summation can be obtained and used as the benchmark for the selection of significant attitude. 


\section{Data Presentation and Analysis}

\subsection{Presentation of Data Analysis and Interpretation}

Table 1 shows how questionnaire was administered and the copies that the researcher was able to retrieve. Fifty copies were shared in Eleme Petrochemical Company Limited (EPCL) and forty-three copies were retrieved. In Atlas Cement Company Limited ten copies were administered and seven copies retrieved, while forty copies were administered in Port Harcourt Refinery Company Limited (PHRC) and twenty-seven copies were retrieved. Again, twenty copies were administered in MTN Communications Limited and twelve copies were retrieved. In SCOA Motors, ten copies were administered of which six were retrieved and finally, in B. J. Oil and Gas Services Company Limited twenty copies were administered and eighteen copies retrieved. Generally, the highest percentage of copies not retrieved from the organisations is forty percent and overall percentage of copies not retrieved is 24 percent.

The table shows a high level of middle level management personnel as respondents with 94.7 percent and 5.3 percent for top level management participation, while lower level management level did not participate in the research responses.

Research Question 1: What are the procedures adopted in recruitment of personnel?

Adopted Table 3 below takes care of the needs of research question 1.

From Table 3, the analysis revealed that the procedures adopted in recruitment of personnel are job analysis with a total score of 348, and mean score of 3.08; application letter, with a total score of 376 and mean score of 3.33; preliminary interview with a total score of 350 and mean score of 3.1; and tests (intelligence, aptitude, achievement, interest, personality, situational, judgement and projective tests), with a total score of 347 and mean score of 3.07.

Others are final interview with a total score of 371 and mean score of 3.28; medical examination with a total score of 390 and mean score of 3.45; and employment with a total score of 356 and mean score of 3.15. The procedures adopted in recruitment of personnel are job analysis, application letter, preliminary interview and tests. Other procedures are final interview, medical examination and employment.

Research Question 2: To what extent do the recruitment procedures used in the organisation influence personnel behaviour?

Table 4 below takes care of the needs of Research Question 2

From Table 4, the analysis reveals that staff employed through "back door" are not effective with a total score of 346 and mean score of 3.1; that due to influences on the recruitment processes and procedures there is disaffection amongst staff members with a total score of 318 and mean score of 2.8; and disloyalties to the organisation with a total score of 318 and mean score of 2.8 as well. The analysis further revealed that due to influences on recruitment processes and procedures, tribalism amongst staff members exist with a total score of 315 and mean score of 2.8; hypocrisy ('eye service') exist with a total score of 313 and mean score of 2.8 .

Analysis of Table 4 further revealed that with influences on recruitment processes and procedures staff members are not very efficient with a total score of 308 and mean score of 2.7 and that there is disharmony in the organisation to certain extent with a total score of 300 and mean score of 2.7 but workers do not change employment so much due to influences on the recruitment processes and procedures in organisations. Therefore, it can be said that the recruitment procedures used in the organisation influences personnel behaviour to a large extent.

Research Question 3: To what extent do the recruitment procedures used in the organisation influence personnel performance?

Table 5 below takes care of the needs of Research Question 3.

From Table 5, the analysis revealed that recruitment processes influence workers' performance with a total score of 353 , mean score of 3.12 and standard deviation of 32.9 and that staff employed through "back door" are not always effective with a total score of 346, mean score of 3.06 and standard deviation of 32.26. But staff employed through "back door" are not usually efficient with a total score of 329, mean score of 2.91 and standard deviation of 30.68. Therefore, recruitment procedures used in the organisation influence personnel performance to a very large extent as revealed by the analysis of Table. 5 .

Research Question 4: To what extent do Communities' influence Personnel recruitment in Organisations?

Table 6 below takes care of the needs of Research Question 4. 
From Table 6, the analysis revealed that recruitment is strictly based on qualification with a total score of 348 , mean score of 3.08 and standard deviation of 32.45 and that despite that, community pressure still influence the recruitment processes and procedures in organisations with a 336, 2.97 and 31.33 the total score, mean score and standard deviation respectively. Notwithstanding, the community pressure does not have much impact on the organisational development with a total score of 318 , mean score of 2.81 and standard deviation of 29.65 . To a very large extent, therefore, communities' influence personnel recruitment in organisations based on the analysis of Table 6

Research Question 5: What factors militate against recruitment processes in the Organisations?

Table 7 below takes care of the needs of Research Question 5

From Table 7 above, the analysis revealed that the factors militating against recruitment processes in the organisation include pressures from Host Communities with a total score of 379 and mean score of 3.35; Quota system with a total score of 345 and mean score of 3.05; Tribalism with a total score of 334 and mean score of 2.96; influence from Board of Directors with a total score of 331 and mean score of 2.93; and imposition with a total score of 323 and mean score of 2.86 .

Other factors militating against recruitment processes as revealed by the analysis of Table 7 above are Geo-political Representation and Nepotism with Total score of 322 and mean score of 2.85 each; and Influence from Head of Government with a total score of 312 and mean score of 2.76 .

Though, factors like political affiliation/membership big shareholders, company financiers, politician with political game and kingmakers were found to be insignificant based on the computation of the data and analysis of Table 7; it must be noted that the level of impact of these factors are insignificant. However, they are still noticeable factors militating against recruitment processes.

Therefore, factors militating against recruitment processes are pressures from host communities, quota system, geo-political representation and imposition. Other factors are political affiliation/membership, nepotism, tribalism, board of directors and head of government.

Research Question 6: What are the likely effects of such community recruitment on organisational development?

Table 8 below takes care of the needs of Research Question 6

As revealed by the analysis of Table 8 , the effects of community recruitment are relegation of meritocracy to the background with a total score of 327 and mean score of 2.9; inability of the organisation to cope with threat and opportunity with a total score of 319 and mean score of 2.8; disaffection amongst staff members and disloyalties to the organisation with a total score of 318 and mean score of 2.8 each.

The analysis of Table 8 further revealed tribalism amongst staff members with a total score of 315 and mean score of 2.8; increase in cost of manpower development with a total score of 314 and mean score of 2.8; hypocrisy ('Eye Service") with a total score of 313 and mean score of 2.8; irregular attendance, low performance of organisation and inefficiency of staff members with a total score of 308 and mean score of 2.7 each. Others are low productivity of the organisation with a total score of 305 and mean score of 2.7; and disharmony within the organisation with a total score of 300 and mean score of 2.7 .

In summary, the likely effects of community recruitment on organisational development are relegation of meritocracy to the background, inability of the organisation to cope with threat and opportunity, disaffection amongst staff members and disloyalties to the organisation. Others are tribalism amongst staff members, increase in cost of manpower development, hypocrisy ("eye service"), irregular attendance, low performance of organisation and inefficiency of staff members. We have also low productivity of the organisation and disharmony within the organisation.

\subsection{Hypotheses Testing}

\section{Research Hypothesis 1}

There is no significant difference in the ranks of male and female perception of personnel recruitment process and personnel performance.

Table 9 below takes care of the needs of Research Hypothesis $1\left(\mathrm{H}_{\mathrm{O}} 1\right)$

From the analysis of Table 9, the calculated value (Rho) of 0.17 is less than the table/critical value of 0.6833 at the alpha level of 0.05 . Since calculated value is less than the critical value we thereby accept the null hypothesis $\left(\mathrm{H}_{0}\right)$ which states that there is no significant difference in the rank of male and female perception of personnel recruitment process and personnel performance. 


\section{Research Hypothesis 2}

There is no significant difference in the ranks of male and female perception of personnel recruitment process and organisational development.

Table 10 below takes care of the needs of Research Hypothesis 2.

From Table 10, the calculated value (Rho) of 0.16 is less than the table/critical value of 0.745 at 0.05 level of significance. Since, the calculated value is less than the critical value, we hereby accept the null hypothesis $\left(\mathrm{H}_{0}\right)$ which states that there is no significant difference in the ranks of male and female perception of personnel recruitment process and organisational development.

In the final analysis it was discovered that job analysis, application letter, preliminary interview, tests, final interview, medical examination and employment as the procedure adopted in recruitment of personnel into organisations studied. Again, the recruitment procedures used in the organisation influence personnel behaviour and personnel performance to a large extent.

Furthermore, it was revealed that communities influence personnel recruitment in organisations to a very large extent and that factors militating against recruitment processes in organisations include pressures from host communities, quota system and geo-political representation. Others are imposition, political affiliation/membership, nepotism, tribalism, board of directors, and heads of government.

On the other hand, the effects of community recruitment on organisational development are disaffection amongst staff members, relegation of meritocracy to the background and inability of the organisation to cope with threat and opportunity. Others are disloyalties to the organisation, tribalism amongst staff members, hypocrisy ('Eye Service') and irregular attendance. We have also low performance of organisation and inefficiency of staff members, low productivity of the organisation and disharmony within the organisation.

The two null hypotheses postulated for the study were accepted which indicates that there is no significant difference in the ranks of male and female perception of personnel recruitment process and personnel performance; as well as personnel recruitment process and organisational development.

\section{Discussion of Findings, Conclusion and Recommendations}

\subsection{Discussion of Findings}

The findings of this study have been grouped and discussed under four broad sub-headings viz.

1) Recruitment processes and procedures.

2) Impacts of recruitment processes on workers performance and organisational development.

3) Factors militating against recruitment processes.

4) Consequences of influences on recruitment processes and organisational development.

\subsubsection{Recruitment Processes and Procedures}

The study revealed that the following processes and procedures are commonly followed by organisations. These include job analysis, application letter, preliminary interview, final interview, medical examination and employment. This is supporting the recruitment processes and procedures postulated by DeCenzo and Robbins (2003).

The study further revealed that there is no particular sequence of recruitment processes and procedures generally used by every organisation. The processes and procedures depend largely on the size of the organisation, the philosophy of the organisation personnel management, the type of vacancy to be filled and more importantly, the external forces. But there are some specific steps that are commonly used by most organisations. This is attested to by Flippo (1984); Rao and Rao; (1990) Cole (2002) and DeCenzo and Robbins (2003) and that there are certain salient feature very commonly used in every recruitment processes and procedures. As revealed by the study, the salient features include application details, interview and selection tests.

It is, therefore, pertinent to note from the result, that recruitment processes and procedures are used in organisations but not followed in the same sequence by all the organisations. Again, no matter how the sequence is followed by organisations certain salient features must be used in any recruitment exercise.

Moreover, the study revealed that certain processes and procedures are not frequently used in organisations like scouting for applicants, written examination and group discussion. The implication of not using scouting for applicant, for instance, is that organisations now wait until a candidate is made whatever he/she is and introduce himself/herself as an applicant. No more 'catch them young' syndrome. The effect of this, is that, those organisations that 'catch them 
young' from schools and colleges employ the best among them and leave the remnant for other organisations to manage with.

Based on this, therefore, the researcher is of the opinion that a section or a committee must exist in every organisation's human resources department to be charged with the responsibility of monitoring undergraduate from school and catch the young graduate very young. Also, the sequence of the personnel recruitment processes and procedures must be designed in line with the organisation size, the philosophy of the organisation personnel management and the type of vacancy to be filled. Such sequence of the personnel recruitment processes must be adopted strictly to the point that even everybody including outsiders will know it is a culture of the organisation. This will reduce drastically both the external and internal influences on the personnel recruitment processes and procedures.

\subsubsection{Impact of Recruitment Processes on Workers Performances and Organisational Development}

The study revealed that personnel recruitment processes and procedures have much impact on the workers performances as well as organisational development. The study, further, established that workers that came into organisation through certain influences and/or forces tend to be more loyal to those forces than the organisation that employed such employee. This attests to Fubara (1984) and Cole (2002) views that arising from the open knowledge of political appointments rather than merit-based appointments, it becomes normal to seek to satisfy the powers that be. This is also supporting Odikpo (1988:147) and Afolabi (1988:8).

The study goes a long way in affirming the preposition of Fubara (1984) and the presumption of the researcher that personnel employed through certain negative influences into organisations are often ineffective and inefficient. This is not because they are not capable but because the influences are still around the corner to influence their performances.

Moreso, the study established that where the employee assisted to get employment does not want to obey the influencing power, there will definitely be a problem, which will hitherto affect the performance of such employee as established in Fubara (1984) that the power game negatively influences the already misconceived corporate shared values. The study revealed why most of our organisations have dismal performance. This is due to the fact that organisation find it difficult to employ staff who can consistently fulfil their roles and will be capable of taking on increase responsibilities. Such personnel Cole (2002) concluded will not be able to cope with opportunities and threats arising from their operating environment. This, the study established, is because such organisation with influenced recruitment exercise will be struggling to build and maintain their workforce. This conclusion is supporting Fubara (1984), Flippo (1984) and Cole (2002).

It must, therefore, be noted that personnel recruitment processes and procedures have much impact on the workers' performances as well as the organisational development. This is telling every employer that most applicant that fit into the job may not necessarily be interested in "bulldozing" their way into an organisation.

Organisation should, therefore, base employment strictly on qualification and merit. But what makes the qualification and merit must be well defined and spelt out for every "dick and harry" to understand. If this is adhered to strictly, influences will be reduced drastically, better employees employed and high organisational development experienced. It must be noted that in most cases, the attitude and the influence from the influencing power that help secure the appointment are usually undefined and sometimes unconscious in influencing the employee.

\subsubsection{Factors Militating against Recruitment Processes}

This study revealed that certain factors militate against personnel recruitment processes. Those factors include: pressures from host community, quota system, imposition, geo-political representation, nepotism, tribalism, pressures from board of directors, head of government, kingmakers, big shareholders and company financier. The findings are in line with Ogunsanwo (1983); Fubara (1984); Odikpo (1988); Popoola (1988); Rao and Rao (1990) and Ugoji (1995:54). They all agreed that certain factors militate against proper recruitment processes with certain influences which makes recruitment exercises shadow of itself.

It is, therefore, established that certain factors hamper the recruitment processes and procedures in our organisation. For instance, Fubara (1984) referred to those factors as power behind the veil and listed them to include pressures from board of directors, relevant ministries, head of government, and kingmakers. Afolabi (1988:7), and Rao and Rao (1990) emphasised local candidates (son-of-the-soil) to have become conveniently handy to leadership appointment as well as local pressures.

All the identified factors militating against personnel recruitment make it difficult for many less privilege individuals to secure appropriate job in organisations and even, achieving something reasonable except when they are ready to pay their way through in cash and/or in kind. This must be discouraged in all ramifications and the entire populace sensitise 
on insisting that the due process must be followed. As a result, the best candidates will be employed and such employees will stay to give their best to the organisation as revealed in Cumming (1975). This is not saying that assistance should not be appreciated but not until due processes had been followed.

\subsubsection{Consequences of Influences on Recruitment Processes and Organisational Development}

The findings of this study revealed that recruitment processes are influenced as such certain consequences arise both positive and negative; but the negative consequences outweigh or rather overshadow the positive consequences.

This is to buttress the postulation of Mathis and Jackson (1997) that the activities that focus on human resources management can provide a direct contribution to organisation performance. Such contribution Mathis and Jackson concluded can be positive or negative, depending on the effectiveness of employees and the implementation of the human resources policies and procedures.

It must be noted that the determining factor here is the influencing factors. As earlier exposed in 5.2.2 of this study that the influencing factor consciously or unconsciously refuse to withdraw outrightly from the employee after influencing such employee's recruitment and in most cases it is not to the advantage of the organisation.

Apparently, the most identified consequences in this study include relegating meritocracy to the background for mediocrity as affirmed in Ugoji (1995:65) for the fact that recruitment are not usually based on merit as expected. Again, the findings revealed that there is inability of organisation to cope with threats and opportunities when they are not able to find and employ staff who consistently fulfil their roles and are capable of taking on increased responsibilities; such organisations are immeasurably not better placed as the organisation will always be struggling to build and maintain their workforce as asserted in Cole, 2002.

Furthermore, disaffection among staff member is another consequence revealed by the findings. Employees recruited through imposition rather than merit-based appointment is always 'stranger' in such environment. This outcome is supporting Odikpo (1988:147), Afolabi (1988:8) and Ugoji (1995:56) who opined that such imposition leads to hypocrisy within the system and that it becomes normal to seek to satisfy the powers that be, but not the organisation. This, as well, inject bad blood, the study revealed, into the system culminating in tension generating crises that can engulf the system and threaten the peaceful tranquility, progress as well as the very good existence of the system.

The findings further revealed that there is increase in the rate of labour turnover of diligent and uncompromising workers who feel cheated, disturbed and worried at the instances of influenced recruitment and its effects on their performance and efficiency. Thereby such employee 'throw-in the towel' for a better job in a more strict environment; or rather becomes uncommitted to the job by practicing irregular attendance and wastage which will result in low productivity and high cost of production; not forgetting that job satisfaction is a positive emotional state.

Another revelation from the findings is that there is inefficiency being experienced generally and consequently low or dismal performance of the organisation. This is supporting Mathis and Jackson (1997) and Odukoya (2004:43) that individual workers are rightly linked to their jobs for organisational success and that in a competitive environment, many organisations do not succeed over the long term. Those that succeed need continuous contributions from the employees in the organisation to become successful and continue their success over time.

The findings made us to realise that when recruitment are influenced there is high tendency that loyalties and allegiances will be shifted from the organisation to the union. This revelation supported DeCenzo and Robbins (2003) assertion that management frequently resists unionization for fear that the union will redirect employee loyalties and allegiances from the organisation to the union. Employees may associate themselves more with the interests of their union than with their employing organisation as employees see their employer as an oppressor. This can, therefore, result in reduced employee commitment, lower morale, resistance to change, and sublimation of the organisation's goals to those of the union or the recruitment influencing power.

It must, therefore, be noted that high rate of labour turnover is expensive especially in the areas of employing new workers, training and retraining the workers, that is, increase in cost of manpower development. All these push the overall cost of production up including loss in labour man-hour as a result of absenteeism and so on. The organisation now produces with a high cost trying to compete with other organisation that produces at a relatively lower cost. Therefore, influences on personnel recruitment processes and procedures must not be encouraged in organisations because of its much adverse effect on the organisation.

\subsection{Summary of the Findings}

The major findings of the study include: 
1) That job analysis, application letter, preliminary interview, final interview, medical examination and employment are the procedures adopted in recruitment of personnel.

2) That the recruitment procedures used in the organisation influences personnel behaviour to a large extent.

3) That to a large extent, employee performance is influenced by the recruitment processes and procedures used in recruiting such employee.

4) That to a very large extent, communities influence personnel recruitment in organisation.

5) Those pressures from host communities, government regulations, staff members' influences and power behind the veil influences are factors that militate against recruitment processes in the organisations.

6) That the influence on the recruitment processes and procedures have adverse effects and consequences on the individual employee as well as the organisation.

7) That there is no significant difference in the ranks of male and female perception of recruitment process and personnel performance. Also, there is no significant difference in the ranks of male and female perception of recruitment process and organisational development.

\subsection{Conclusion}

The results exposed a high level of retrieval of questionnaire administered and much participation of middle level management personnel of the organisations studied.

The outcome of the study revealed that to a large extent personnel recruitment process influence organisational development. It is, therefore, pertinent for organisations to develop a particular recruitment processes and procedures and ensure strict compliance. If employees are recruited through what we considered as 'front door' and not 'back door' there is much tendency that employee's attitude to work will be changed for enhanced productivity and organisational development.

\subsection{Recommendations}

The following recommendations will help reduce the dismal performance of our organisations as revealed by the study.

1) Recruitment processes and procedures must be developed in line with the identified sequence in the study and based on every organisation size and philosophy of personnel management.

2) All applicants must be made to pass through the identified recruitment processes and procedures; and the selection must strictly be based on merit and qualification.

3) Qualification and merit must be well spelt out to include individual abilities to 'deliver' and not just 'paper' qualification.

4) Organisations must give all applicants equal opportunities to prove their worth; no sacred cow syndrome.

All the above are to reduce the influences and pressures on the recruitment processes and procedures. This should enable organisations to recruit better personnel which would enhance better personnel performance and high organisational development.

\section{References}

Afolabi, H. B. (1988). Trends, Challenges and Management Strategies in University Administration in Nigeria. Committee of Registrar of Nigeria (CORNU) Seminar, Anambra State University of Technology, $5^{\text {th }}-6^{\text {th }}$ May.

Ahiauzu, A. (1999). The African Industrial Man. Port Harcourt: CIMRAT.

Ananaba, W. (1969). The Trade Union Movement in Nigeria. Benin City: Ethiope Publishing Corporation.

Anyanwu, A. (2000). Research Methodology in Business \& Social Sciences. Owerri: Canon Publishers Ltd.

Beckhard, R. (1969). Organisation Development: Strategies and Models. Addison: Wesley Publishing Company.

Byars L. L., \& Rue L.W. (1984). Human Resources and Personnel Management. Homewood, Illinois: Richard D. Irwin Inc.

Cole, G. A. (2002). Personnel and Human Resources Management. London: Educational Low-Priced Sponsored Texts with Continuum.

Cummings, T. G. (1978). Self Regulating Work Groups: A Socio-Technical Synthesis. Academy of Management Review, 3, 625-634. 
DeCenzo, D. A., \& Robbins S. P. (2003). Personnel/Human Resources Management. New Delhi, Prentice Hall of India Private Ltd.

Ezewu, E. E., \&Ukwuije, R.P.I. (1989). Empirical Research Procedures and Statistics for Education Students. Ughelli: Eddy Joe Publishers.

Fapohunda, O. (1977). Employment and Unemployment in Lagos. Institute of Social Studies Occasional Papers, Netherlands: The Hague.

Flippo E. B. (1984). Personnel Management. New York: McGraw-Hill Books.

Fraser, J. M. (1978). Employment Interviewing. New York: MacDonald \& Evans.

Fubara, B. A. (1984). Power Behind the Veil in Public Enterprises in Developing Countries. A Case Study of Policy Formulation. Pakistan Administration, 21, 1-12.

Fubara, B. A. (1985). Business Management: Principles and Strategies. Ibadan: University Press Plc.

Glueck, W. F. (1978). Personnel: A Diagnostic Approach. Dallas: Business Publications.

Johnnie P. B., \& Nwasike J. N. (2002). Organisational Behaviour and Advanced Management Thought (An Epistemological Analysis). Lagos: UNILAG Press.

Johnnie, P. B. (2002). Organisational Behaviour and Organisational Theory (A Theoretical and Philosophical Perspective). Lagos: UNILAG Press.

Kosemani J. M. (2000). Nigerian Education: Matters Arising (Vol. 1). Port Harcourt: Abe Publishers.

Lewin, K. (1951). Field Theory in Social Science. New York: Harpers and Brothers.

Lewis, C. (1985). Employee Selection. Hutchinson: MacDonald \& Evans

Mathis, L. R., \& Jackson, H. J. (1997). Personnel: Human Resource Management. New York: West Publishing Company.

Meyer H. E. (1976). Fortune Magazine. India: February, pp. 88-90.

Ocho, L. O. (1984). Cultural and Environmental Influences on Work Attitudes. In Ejiofor P. N. O. and Aniagoh V. A. (Eds.), Managing the Nigerian Worker. Ibadan: Longman.

Odikpo, C. K. (1988). Effective Structure of University Administration, - Resources Management in the University System, Proceedings of the International Seminar of the National University Commission (Committee of vice-chancellors) British Council, Ahmadu Bello University, Zaria, $9^{\text {th }}-10^{\text {th }}$ Nov.

Odukoya, E. A. (2004). Factors Responsible for Employee Turnover and Productivity (Unpublished MBA Thesis). Rivers State University of Science and Technology, Port Harcourt.

Ogolo, M. B. (1996). Student's Guide to Writing Research and Project Proposals. Port Harcourt: City-Creeks Publishers.

Ogunsanwo, O. A. (1983). Power Environment and Goal Achievement: Analysis of Some Organisational Correlates in Selected Nigerian Universities. Unpublished Ph.D. Dissertation, Ahmadu Bello University, Zaria.

Omolayo, A. B., \& Olatunji-Sule B. M. (2002). A Study on Student's Attitude towards Mathematics in Secondary Schools: A Study of Obio/Akpor Local Government Area of Rivers State. Unpublished B.Sc. Research Project of the University of Port Harcourt, Port Harcourt.

Ottih, L. O. (2002). Organisation Theory: Structure, Design and Process (Unpublished Instructional Manual).

Pigors, P., \& Myers, C. A. (1961). Personnel Administration. Kogakusha: McGraw-Hill.

Popoola, J. O. (1988). Changes in the Nigerian University System. The Committee of Registrars of Nigerian Universities (CORNU) Seminar. $21^{\mathrm{ST}}$ October.

Rao, P. S., \& Rao V.S.P (1990). Personnel/Human Resources Management: Text, Cases and Games. Delhi: Komark.

Rodger, A. (1950). In Cole, G. A. (Ed.), Personnel and Human Resources Management (2002). London: Educational Low-Priced Sponsored Texts with Continuum.

Ugoji, E. I. (1995). Administrative Stress and Coping Strategies Amongst Top Nigerian University Administrators (Unpublished Ph.D. Thesis). Imo State University, Owerri.

Yesufu, Y. M. (1962). An Introduction to Industrial Relations in Nigeria. London: Oxford University Press. 
Table 1. Administration and retrieval of questionnaire

\begin{tabular}{lcccrr}
\hline \multicolumn{1}{c}{ Organisations } & $\begin{array}{c}\text { Copies } \\
\text { Administered }\end{array}$ & $\begin{array}{c}\text { Copies } \\
\text { Retrieved }\end{array}$ & \% & $\begin{array}{c}\text { Copies Not } \\
\text { Retrieved }\end{array}$ & \% \\
\hline EPCL & 50 & 43 & 86 & 7 & 14 \\
Atlas Cement & 10 & 7 & 70 & 3 & 30 \\
PHRC & 40 & 27 & 67.5 & 13 & 32.5 \\
MTN Comm. Ltd. & 20 & 12 & 60 & 8 & 40 \\
SCOA Motors & 10 & 6 & 90 & 4 & 40 \\
B. J. Oil \& Gas Ltd. & 20 & 18 & $\mathbf{7 5 . 3}$ & $\mathbf{3 7}$ & 10 \\
\hline \multicolumn{1}{c}{ Total } & $\mathbf{1 5 0}$ & $\mathbf{1 1 3}$ & $\mathbf{2 4 . 7}$ \\
\hline
\end{tabular}

Source: Survey Data, 2004

Table 2. Management level of respondents in the organisation

\begin{tabular}{lccc}
\hline \multicolumn{2}{c}{ Management Level } & Number of Respondents & Percentage (\%) \\
\hline Lower level & - & - \\
Middle level & 107 & 94.7 \\
Top level & Total & 6 & 5.3 \\
\hline & $\mathbf{1 1 3}$ & $\mathbf{1 0 0}$ \\
\hline
\end{tabular}

Source: Survey Data, 2004

Table 3. Recruitment processes and procedures in organisations

\begin{tabular}{clrrr}
\hline Item No. & \multicolumn{1}{c}{ Description } & $\begin{array}{c}\text { Total Score } \\
\text { (TS) }\end{array}$ & $\begin{array}{c}\text { Mean Score } \\
\text { (MS) }\end{array}$ & $\begin{array}{c}\text { Standard } \\
\text { Deviation } \\
\text { (STD) }\end{array}$ \\
\hline 1. & Job Analysis & 348 & $* 3.08$ & 32.45 \\
2. & Scouting for Applicant & 249 & 2.20 & 23.22 \\
3. & Application Form/Letter & 376 & $* 3.33$ & 35.06 \\
4. & Written Examination & 239 & 2.12 & 22.28 \\
5. & Preliminary Interview & 350 & $* 3.10$ & 32.63 \\
6. & Group Discussion & 240 & 2.12 & 22.38 \\
7. & Tests (Intelligence, aptitude, etc.) & 347 & $* 3.07$ & 32.35 \\
8. & Final Interview & 371 & $* 3.28$ & 34.59 \\
9. & Medical Examination & 390 & $* 3.45$ & 36.36 \\
10. & Reference Checks & 318 & 2.81 & 29.65 \\
11. & Final Decision by the Line Manager & 318 & 2.81 & 29.65 \\
12 & Employment & 356 & $* 3.15$ & 33.19 \\
& & & $\mathbf{3 4 . 5 2}$ & $\mathbf{3 6 3 . 8 1}$ \\
\hline & & Benchmark $=2.88$ & 30.32
\end{tabular}

* Significant

Source: Survey Data, 2004

Table 4. Impact of recruitment processes on workers behaviour

\begin{tabular}{|c|c|c|c|}
\hline Item No. & $\begin{array}{r}\text { Description } \\
\end{array}$ & $\begin{array}{c}\text { Total Score } \\
\text { (TS) }\end{array}$ & $\begin{array}{c}\text { Mean Score } \\
\text { (MS) }\end{array}$ \\
\hline 1. & Disaffection amongst staff members & 318 & $* 2.8$ \\
\hline 2. & Hypocrisy ('Eye Service’) & 313 & *2.8 \\
\hline 3. & Disloyalties to the Organisation & 318 & *2.8 \\
\hline 4. & Disharmony within the Organisation & 300 & 2.7 \\
\hline 5. & Labour Turnover & 274 & 2.4 \\
\hline 6. & Tribalism amongst Staff Members & 315 & $* 2.8$ \\
\hline 7. & Inefficiency of Staff members & 308 & 2.7 \\
\hline 8. & $\begin{array}{l}\text { Staff employed through "back door" are } \\
\text { ineffective }\end{array}$ & 346 & $* 3.1$ \\
\hline & Total: & 2,492 & 22.0 \\
\hline & Benchmark $=$ & 312 & 2.8 \\
\hline
\end{tabular}

* Significant

Benchmark $=$ 
Table 5. Impact of recruitment processes on workers' performances

\begin{tabular}{|c|c|c|c|c|}
\hline Item No. & Description & $\begin{array}{l}\text { Total Score } \\
\text { (TS) }\end{array}$ & $\begin{array}{l}\text { Mean Score } \\
\text { (MS) }\end{array}$ & $\begin{array}{c}\text { Standard } \\
\text { Deviation } \\
\text { (STD) }\end{array}$ \\
\hline 1. & $\begin{array}{l}\text { Recruitment processes influence workers } \\
\text { performance }\end{array}$ & 353 & $* 3.12$ & 32.90 \\
\hline 2. & $\begin{array}{l}\text { Staff employed through "back door" are } \\
\text { ineffective }\end{array}$ & 346 & $* 3.06$ & 32.26 \\
\hline \multirow[t]{3}{*}{3.} & $\begin{array}{l}\text { Staff employed through "back door" are } \\
\text { inefficient }\end{array}$ & 329 & 2.91 & 30.68 \\
\hline & \multirow{2}{*}{$\begin{array}{r}\text { Total: } \\
\text { Benchmark }=\end{array}$} & 1,028 & 9.09 & 95.84 \\
\hline & & 343 & 3.03 & 31.95 \\
\hline
\end{tabular}

* Significant

Source: Survey Data, 2004

Table 6. Communities' influence on personnel recruitment processes

\begin{tabular}{|c|c|c|c|c|}
\hline Item No. & Description & $\begin{array}{l}\text { Total Score } \\
\text { (TS) }\end{array}$ & $\begin{array}{l}\text { Mean Score } \\
\text { (MS) }\end{array}$ & $\begin{array}{c}\text { Standard } \\
\text { Deviation } \\
\text { (STD) }\end{array}$ \\
\hline 1. & Recruitment is strictly based on qualification & 348 & $* 3.08$ & 32.45 \\
\hline 2. & $\begin{array}{l}\text { Community pressure influences recruitment } \\
\text { processes }\end{array}$ & 336 & $* 2.97$ & 31.33 \\
\hline \multirow[t]{3}{*}{3.} & $\begin{array}{l}\text { Community pressure affect development of } \\
\text { organisation }\end{array}$ & 318 & 2.81 & 29.65 \\
\hline & \multirow{2}{*}{$\begin{array}{r}\text { Total: } \\
\text { Benchmark }=\end{array}$} & 1,002 & 8.86 & 93.43 \\
\hline & & 334 & 2.95 & 31.14 \\
\hline
\end{tabular}

* Significant

Source: Survey Data, 2004

Table 7. Factors militating against recruitment processes

\begin{tabular}{|c|c|c|c|c|}
\hline Item No. & Description & $\begin{array}{c}\text { Total Score } \\
\text { (TS) }\end{array}$ & $\begin{array}{c}\text { Mean Score } \\
\text { (MS) }\end{array}$ & $\begin{array}{c}\text { Standard } \\
\text { Deviation } \\
\text { (STD) }\end{array}$ \\
\hline 1. & Pressures from Host Communities & 379 & $* 3.35$ & 35.34 \\
\hline 2. & Pressures from Labour Union Executives & 261 & 2.31 & 24.34 \\
\hline 3. & Quota System & 345 & $* 3.05$ & 32.17 \\
\hline 4. & Geo-Political Representation & 322 & $* 2.85$ & 30.02 \\
\hline 5. & Imposition & 323 & $* 2.86$ & 30.12 \\
\hline 6. & Political Affiliation/Membership & 308 & $* 2.73$ & 28.72 \\
\hline 7. & Nepotism & 322 & $* 2.85$ & 30.02 \\
\hline 8. & Tribalism & 334 & $* 2.96$ & 31.14 \\
\hline 9. & Selling of Employment Letter & 220 & 1.95 & 20.51 \\
\hline 10. & Board of Directors & 331 & $* 2.93$ & 30.86 \\
\hline 11. & Relevant Ministries & 292 & 2.58 & 27.23 \\
\hline 12. & Head of Government & 312 & $* 2.76$ & 29.09 \\
\hline 13. & Kingmakers & 297 & 2.63 & 27.69 \\
\hline 14. & Big Shareholders & 308 & 2.73 & 28.72 \\
\hline 15. & Company Financier & 309 & 2.73 & 28.81 \\
\hline \multirow[t]{3}{*}{16.} & Politician with Political Game & 307 & 2.72 & 28.62 \\
\hline & Total: & 4,970 & 43.99 & 463.4 \\
\hline & Benchmark $=$ & 311 & 2.75 & 28.96 \\
\hline
\end{tabular}

* Significant

Source: Survey Data, 2004 
Table 8 . Effects of community recruitment on organisational development

\begin{tabular}{|c|c|c|c|}
\hline Item No. & Description & $\begin{array}{c}\text { Total Score } \\
\text { (TS) }\end{array}$ & $\begin{array}{c}\text { Mean Score } \\
\text { (MS) }\end{array}$ \\
\hline 1. & Disaffection amongst staff members & 318 & $* 2.8$ \\
\hline 2. & Relegation of Meritocracy to the Background & 327 & $* 2.9$ \\
\hline 3. & Hypocrisy ("Eye Service”) & 313 & $* 2.8$ \\
\hline 4. & $\begin{array}{l}\text { Inability of the organisation to cope with } \\
\text { threat and opportunity }\end{array}$ & 319 & $* 2.8$ \\
\hline 5. & Disloyalties to the organisation & 318 & *2.8 \\
\hline 6. & Disharmony within the organisation & 300 & $* 2.7$ \\
\hline 7. & Absenteeism (Irregular Attendance) & 308 & $* 2.7$ \\
\hline 8. & Labour Turnover Rate & 274 & 2.4 \\
\hline 9. & Low Productivity & 305 & $* 2.7$ \\
\hline 10. & Increase in Cost of Manpower Development & 314 & $* 2.8$ \\
\hline 11. & High Cost of Production & 294 & 2.6 \\
\hline 12. & Low Performance of Organisation & 308 & $* 2.7$ \\
\hline 13. & Tribalism amongst Staff Members & 315 & $* 2.8$ \\
\hline 14. & Inefficiency of Staff Members & 308 & $* 2.7$ \\
\hline \multirow{2}{*}{\multicolumn{2}{|c|}{$\begin{array}{r}\text { Total: } \\
\text { Benchmark }=\end{array}$}} & 4321 & 38.2 \\
\hline & & 308 & 2.7 \\
\hline
\end{tabular}

* Significant

Source: Survey Data, 2004

Table 9. Spearman rank correlation coefficient of male and female perception of personnel recruitment processes and personnel performance

\begin{tabular}{|c|c|c|c|c|c|}
\hline \multirow[t]{2}{*}{ Item. No. } & \multirow[t]{2}{*}{ Description } & \multicolumn{2}{|c|}{ Ranking } & \multirow[t]{2}{*}{ d } & \multirow[t]{2}{*}{$\mathbf{d}^{2}$} \\
\hline & & Male & Female & & \\
\hline 1 & $\begin{array}{llll}\begin{array}{l}\text { Recruitment } \\
\text { performance }\end{array} & \text { Process } & \text { influence } & \text { workers } \\
\end{array}$ & 2 & 1 & 1 & 1 \\
\hline 2. & Disaffection amongst staff member & 4 & 4 & - & - \\
\hline 3 & Hypocrisy ('Eye Service') & 3 & 8 & -5 & 25 \\
\hline 4. & Disloyalties to the Organisation & 6 & 3 & 3 & 9 \\
\hline 5. & Disharmony within the Organisation & 7 & 5 & 2 & 4 \\
\hline 6. & Labour Turnover & 9 & 9 & - & - \\
\hline 7. & Tribalism & 5 & 5 & - & - \\
\hline 8. & Inefficiency & 7 & 2 & 5 & 25 \\
\hline 9. & $\begin{array}{l}\text { Staff employed through "back door" are often } \\
\text { ineffective }\end{array}$ & 1 & 7 & -6 & 36 \\
\hline
\end{tabular}

Calculated Value: $\rho($ Rho $)=0.17$ and

Critical/Table Value $\alpha=0.05=0.6833$

Table 10. Spearman rank correlation coefficient of male and female perception of personnel recruitment processes and organisational development

\begin{tabular}{|c|c|c|c|c|c|}
\hline \multirow[t]{2}{*}{ Item. No. } & \multirow[t]{2}{*}{ Description } & \multicolumn{2}{|c|}{ Ranking } & \multirow[t]{2}{*}{ d } & \multirow[t]{2}{*}{$d^{2}$} \\
\hline & & Male & Female & & \\
\hline 1 & $\begin{array}{l}\text { Employment through "back door" affect } \\
\text { organisational development }\end{array}$ & 1 & 1 & - & - \\
\hline 2. & $\begin{array}{l}\text { Community pressure often affect development } \\
\text { of organisation }\end{array}$ & 2 & 5 & -3 & 9 \\
\hline 3 & $\begin{array}{l}\text { Inability of the organisation to cope with threat } \\
\text { and opportunity }\end{array}$ & 3 & 5 & -2 & 4 \\
\hline 4. & Low productivity & 4 & 2 & 2 & 4 \\
\hline 5. & Increase in cost of manpower development & 7 & 2 & 5 & 25 \\
\hline 6. & High cost of production & 6 & 7 & -1 & 1 \\
\hline 7. & Low performance of organisation & 4 & 2 & -2 & 4 \\
\hline
\end{tabular}

Calculated Value: $\rho($ Rho $)=0.16$ and

Critical $/$ Table Value $\alpha=0.05=0.7450$ 


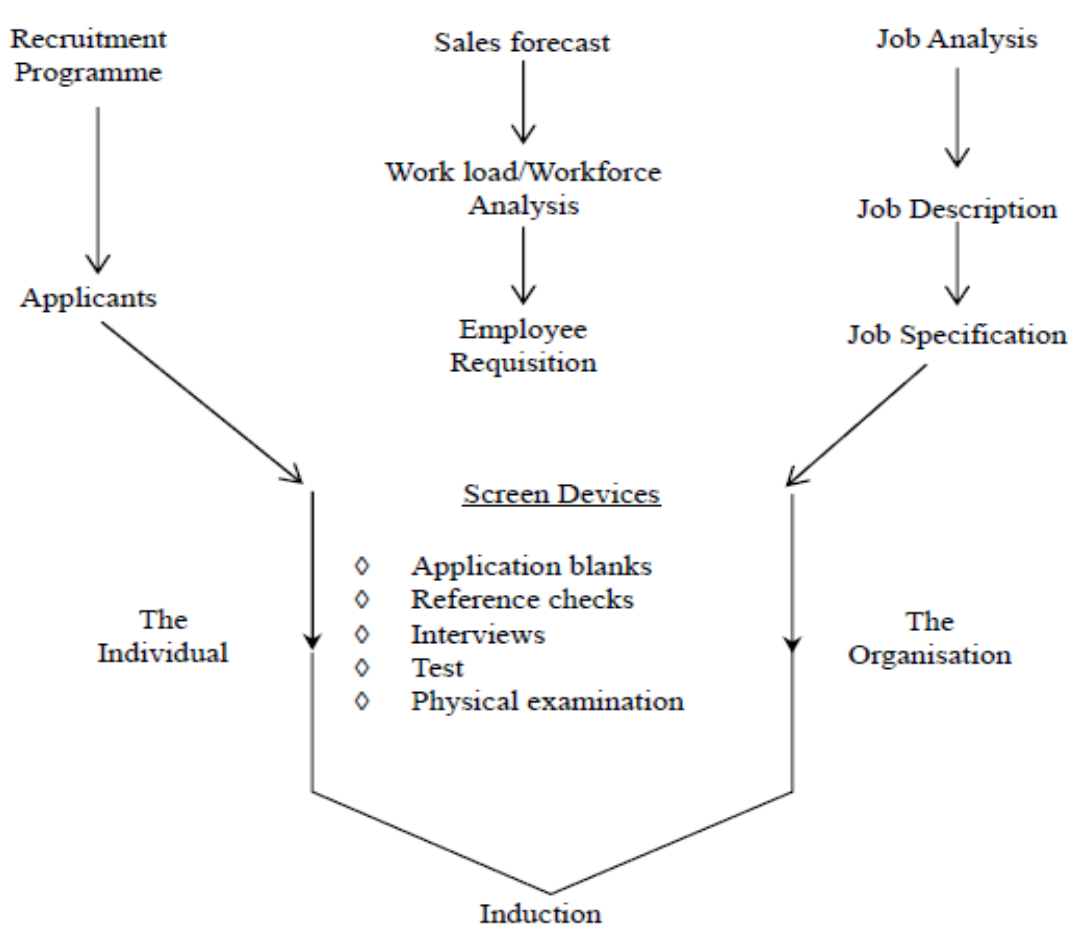

Figure 1. Recruitment framework

Source: Flippo (1984:148)

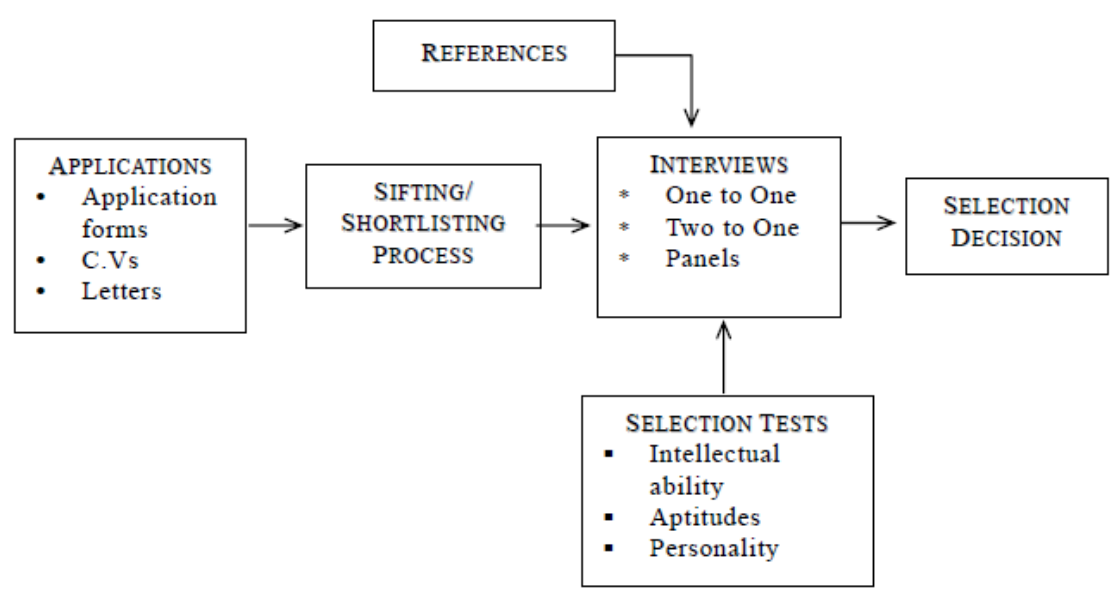

Figure 2. Relationship between recruitment processes salient features

Source: Cole (2002:183) 
APPENDIX I

\begin{tabular}{|c|c|c|c|c|c|c|c|c|c|c|c|}
\hline \multirow{2}{*}{ S/No. } & \multirow{2}{*}{ Description } & \multirow{2}{*}{ SA } & \multirow{2}{*}{ A } & \multirow{2}{*}{ DA } & \multirow{2}{*}{ SDA } & \multirow{2}{*}{ TS } & \multirow{2}{*}{$\begin{array}{l}(\overline{\mathrm{x}}) \\
\text { M.S }\end{array}$} & \multirow{2}{*}{ TS-MS } & \multirow[t]{2}{*}{$(\mathrm{TS}-\mathrm{MS})^{2}$} & $(\mathrm{TS}-\mathrm{MS})^{2}$ & \multirow{2}{*}{$\sqrt{\frac{(\mathrm{TS}-\mathrm{MS})}{\mathrm{N}}}$} \\
\hline & & & & & & & & & & $\mathrm{N}$ & \\
\hline 1. & Job Analysis & 168 & 147 & 24 & 9 & 348 & 3.08 & 344.92 & 118969.81 & 1052.8 & 32.45 \\
\hline 2. & Scouting for Applicants & 40 & 114 & 60 & 35 & 249 & 2.20 & 246.8 & 60910.2 & 539.03 & 23.22 \\
\hline 3. & Application form or application letter & 184 & 174 & 18 & - & 376 & 3.33 & 372.67 & 138882.93 & 1229.05 & 35.06 \\
\hline 4. & Written Examination & 168 & 29 & 28 & 14 & 239 & 2.12 & 236.88 & 56112.13 & 496.57 & 22.28 \\
\hline 5. & Preliminary Interview & 160 & 159 & 22 & 9 & 350 & 3.10 & 346.9 & 120339.6 & 1064.95 & 32.63 \\
\hline 6. & Group Discussion & 36 & 93 & 78 & 33 & 240 & 2.12 & 237.88 & 56586.89 & 500.77 & 22.38 \\
\hline 7. & $\begin{array}{l}\text { Tests (intelligence, aptitude achievement, interest, } \\
\text { etc.) }\end{array}$ & 188 & 123 & 22 & 14 & 347 & 3.07 & 343.93 & 118287.85 & 1046.8 & 32.35 \\
\hline 8. & Final Interview & 192 & 162 & 12 & 5 & 371 & 3.28 & 367.72 & 135218.00 & 1196.62 & 34.59 \\
\hline 9. & Medical Examination & 288 & 78 & 18 & 6 & 390 & 3.45 & 386.55 & 149420.9 & 1322.31 & 36.36 \\
\hline 10. & Reference checks & 116 & 138 & 52 & 12 & 318 & 2.81 & 315.19 & 99344.74 & 879.16 & 29.65 \\
\hline 11. & Final Decision by the Line Manager & 116 & 141 & 48 & 13 & 318 & 2.81 & 315.19 & 99344.74 & 879.16 & 29.65 \\
\hline 12. & Employment & 144 & 198 & 6 & 8 & 356 & 3.15 & 352.85 & 124503.12 & 1101.80 & 33.19 \\
\hline & & 1800 & 1556 & 388 & 158 & 3902 & 34.52 & 3867.48 & 1277920.91 & 11309.02 & 363.81 \\
\hline
\end{tabular}

30.32

Key: $\quad$ SA -4

A - 3

$\mathrm{DA}-2$

SDA- 1

TS - Total Score

MS- Mean/Average Score

$\mathrm{N}=113$

\section{APPENDIX II}

\begin{tabular}{|c|l|c|c|c|c|}
\hline S/No. & \multicolumn{1}{|c|}{ Description } & SA & A & DA & SDA \\
\hline \hline 1. & $\begin{array}{l}\text { Recruitment processes and procedures influence } \\
\text { workers performances in this organisation }\end{array}$ & 176 & 144 & 24 & 9 \\
\hline 2. & Recruitment is strictly based on qualification & 148 & 162 & 32 & 6 \\
\hline 3. & $\begin{array}{l}\text { Employment through the "back door" often affect } \\
\text { organisational development }\end{array}$ & 272 & 111 & 12 & 2 \\
\hline 4. & $\begin{array}{l}\text { Staff employed through "back door" are often } \\
\text { ineffective }\end{array}$ & 160 & 132 & 50 & 4 \\
\hline 5. & $\begin{array}{l}\text { Staff employed through "back door" are often } \\
\text { inefficient }\end{array}$ & 128 & 147 & 44 & 10 \\
\hline 6. & $\begin{array}{l}\text { Staff employed through "back door" are often not } \\
\text { loyal to the organisation }\end{array}$ & 84 & 117 & 92 & 7 \\
\hline 7. & $\begin{array}{l}\text { Communities pressures influence recruitment } \\
\text { processes in this organisation }\end{array}$ & 136 & 156 & 34 & 10 \\
\hline 8. & $\begin{array}{l}\text { Communities pressures often affect development of } \\
\text { this organisation }\end{array}$ & 124 & 144 & 34 & 16 \\
\hline
\end{tabular}

\begin{tabular}{|c|c|c|c|c|c|}
\hline TS & $\begin{array}{c}(\bar{x}) \\
\text { M.S }\end{array}$ & TS-MS & $(\text { TS-MS })^{2}$ & $\frac{(T S-M S)^{2}}{N}$ & $\sqrt{(T S-M S)^{2}}$ \\
\hline \hline 353 & 3.12 & 349.88 & 122416.0 & 1083.33 & 32.9 \\
\hline 348 & 3.08 & 344.92 & 118969.8 & 1052.83 & 32.45 \\
\hline 397 & 3.51 & 393.49 & 154834.4 & 1370.22 & 37.02 \\
\hline 346 & 3.06 & 342.94 & 117607.84 & 1040.78 & 32.26 \\
\hline 329 & 2.91 & 326.09 & 106334.69 & 941.02 & 30.68 \\
\hline 300 & 2.66 & 297.34 & 88411.08 & 782.40 & 27.97 \\
\hline 336 & 2.97 & 333.03 & 110908.98 & 981.50 & 31.33 \\
\hline 318 & 2.81 & 315.19 & 99344.7 & 879.16 & 29.65 \\
\hline \hline
\end{tabular}

BENCHMARK

31.78 
APPENDIX III

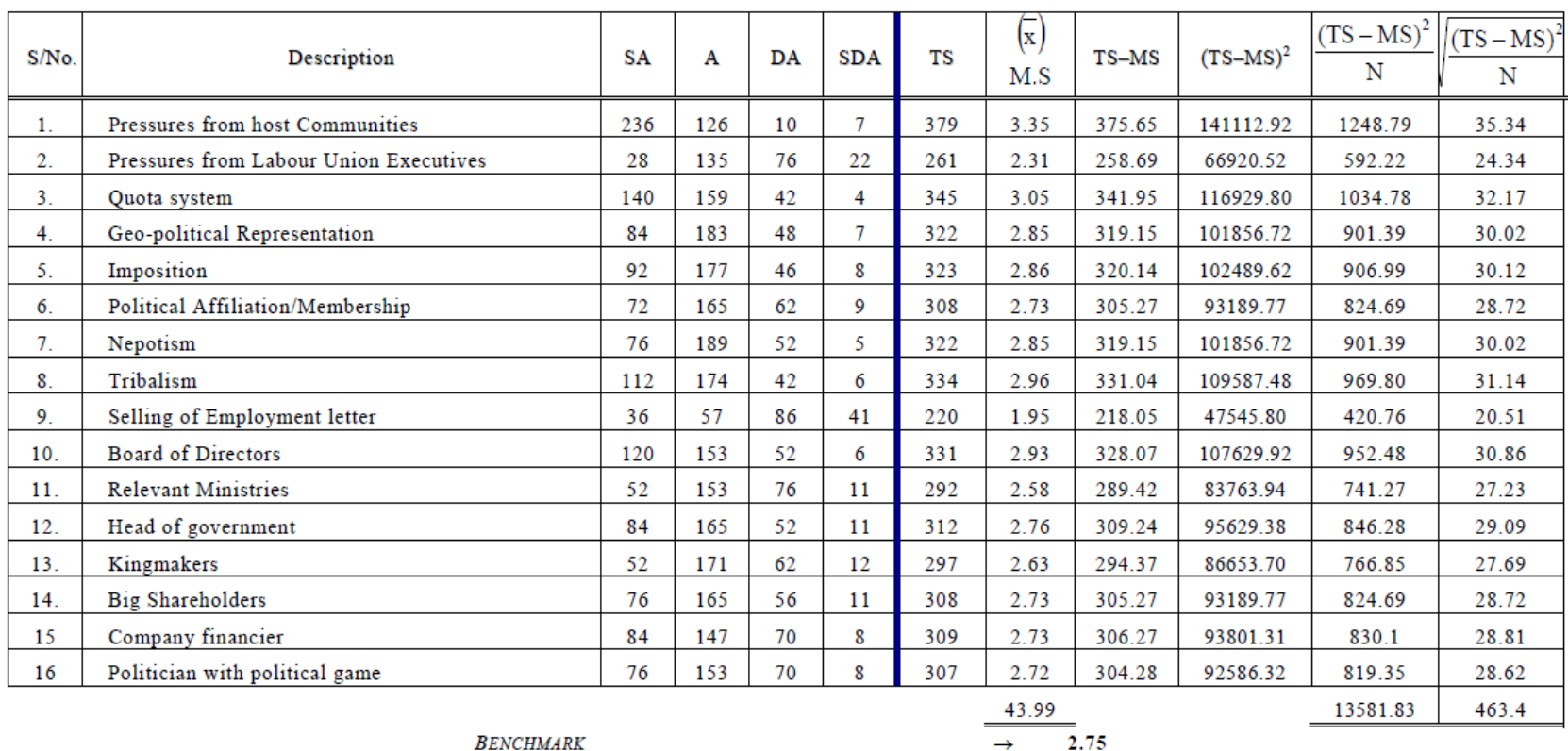

28.96

APPENDIX IV

\begin{tabular}{|c|c|c|c|c|c|c|c|}
\hline S/No. & Description & SA & A & DA & SDA & TS & $\begin{array}{l}\text { (X) } \\
\text { M.S }\end{array}$ \\
\hline 1. & Disaffection among Staff members & 104 & 159 & 42 & 13 & 318 & 2.8 \\
\hline 2. & Relegation of meritocracy to the background & 136 & 141 & 36 & 14 & 327 & 2.9 \\
\hline 3. & Hypocrisy ('Eye Service') & 96 & 150 & 56 & 11 & 313 & 2.8 \\
\hline 4. & $\begin{array}{l}\text { Inability of the organisation to cope with threat and } \\
\text { opportunities }\end{array}$ & 112 & 153 & 40 & 14 & 319 & 2.8 \\
\hline 5. & Disloyalties to the organisation & 80 & 180 & 50 & 8 & 318 & 2.8 \\
\hline 6. & Disharmony within the organisation & 68 & 168 & 48 & 16 & 300 & 2.7 \\
\hline 7. & Absenteeism (Irregular Attendance) & 96 & 138 & 62 & 12 & 308 & 2.7 \\
\hline 8. & $\begin{array}{l}\text { Labour Turnover (Rate at which workers Leave the } \\
\text { job) }\end{array}$ & 52 & 117 & 88 & 17 & 274 & 2.4 \\
\hline 9. & Low Productivity & 96 & 138 & 56 & 15 & 305 & 2.7 \\
\hline 10. & Increase in cost of manpower development & 104 & 150 & 46 & 14 & 314 & 2.8 \\
\hline 11. & High cost of production & 80 & 135 & 62 & 17 & 294 & 2.6 \\
\hline 12. & Low Performance of organisation & 84 & 162 & 48 & 14 & 308 & 2.7 \\
\hline 13. & Tribalism & 72 & 192 & 40 & 11 & 315 & 2.8 \\
\hline 14. & Inefficiency & 100 & 141 & 52 & 15 & 308 & 2.7 \\
\hline \multirow{2}{*}{\multicolumn{6}{|c|}{ BENCHMARK }} & 4321 & 38.35 \\
\hline & & & & & & $\rightarrow$ & 2.7 \\
\hline
\end{tabular}




\section{APPENDIX V}

Hypothesis 1

\begin{tabular}{|c|c|c|c|c|c|c|c|c|c|c|c|c|c|c|c|}
\hline \multirow[b]{2}{*}{ S/No. } & \multirow[b]{2}{*}{ Description } & \multicolumn{4}{|c|}{ Male Score } & \multicolumn{4}{|c|}{ Female Score } & \multicolumn{2}{|c|}{ Total Score } & \multicolumn{2}{|c|}{ Mean Score } & \multicolumn{2}{|c|}{ Ranking } \\
\hline & & $\mathrm{SA}$ & $\mathrm{A}$ & $\mathrm{DA}$ & SDA & SA & $\mathrm{A}$ & DA & SDA & $\mathrm{M}$ & $\mathrm{F}$ & $\mathrm{M}$ & $\mathrm{F}$ & $\mathrm{M}$ & $\mathrm{F}$ \\
\hline 1. & $\begin{array}{l}\text { Recruitment Processes Influence } \\
\text { workers performance }\end{array}$ & 92 & 75 & 6 & 22 & 80 & 69 & 2 & 6 & 195 & 157 & 3 & 3.3 & 2 & 1 \\
\hline 2. & Disaffection among staff Members & 52 & 78 & 10 & 32 & 48 & 84 & 3 & 10 & 172 & 145 & 2.7 & 3.0 & 4 & 4 \\
\hline 3. & Hypocrisy("Eye Service") & 56 & 84 & 9 & 28 & 40 & 69 & 2 & 26 & 177 & 137 & 2.7 & 2.9 & 3 & 8 \\
\hline 4. & Disloyalties to the Organisation & 28 & 84 & 7 & 46 & 52 & 93 & 2 & 4 & 165 & 151 & 2.5 & 3.2 & 6 & 3 \\
\hline 5. & Disharmony within organisation & 36 & 75 & 14 & 34 & 36 & 93 & 1 & 14 & 159 & 144 & 2.5 & 3.0 & 7 & 5 \\
\hline 6. & Labour Turnover & 24 & 66 & 11 & 52 & 28 & 51 & 6 & 36 & 153 & 121 & 2.4 & 2.5 & 9 & 9 \\
\hline 7. & Tribalism & 36 & 93 & 10 & 30 & 40 & 90 & 2 & 12 & 169 & 144 & 2.6 & 3.0 & 5 & 5 \\
\hline 8. & Inefficiency & 44 & 57 & 12 & 46 & 56 & 90 & 1 & 6 & 159 & 153 & 2.5 & 3.2 & 7 & 2 \\
\hline 9. & $\begin{array}{l}\text { Staff employed through "back door" are } \\
\text { ineffective }\end{array}$ & 96 & 69 & 2 & 32 & 56 & 63 & 3 & 20 & 199 & 142 & 3.1 & 3.0 & 1 & 7 \\
\hline
\end{tabular}

Male $65 \quad$ Female 48

\section{APPENDIX VI}

Hypothesis 2

\begin{tabular}{|c|c|c|c|c|c|c|c|c|c|c|c|c|c|c|c|}
\hline \multirow{2}{*}{ S/No. } & \multirow{2}{*}{ Description } & \multicolumn{4}{|c|}{ Male Score } & \multicolumn{4}{|c|}{ Female Score } & \multicolumn{2}{|c|}{ Total Score } & \multicolumn{2}{|c|}{ Mean Score } & \multicolumn{2}{|c|}{ Ranking } \\
\hline & & SA & $\mathrm{A}$ & $\mathrm{DA}$ & SDA & SA & $\mathrm{A}$ & DA & SDA & $\mathrm{M}$ & $\mathrm{F}$ & $\mathrm{M}$ & $\mathrm{F}$ & M & $\mathrm{F}$ \\
\hline 1. & $\begin{array}{l}\text { Employment through "backdoor" often } \\
\text { affect organisational development }\end{array}$ & 152 & 63 & 2 & 8 & 124 & 45 & - & 2 & 225 & 171 & 3.5 & 3.6 & 1 & 1 \\
\hline 2. & $\begin{array}{l}\text { Communities pressures often affect } \\
\text { development of organisation }\end{array}$ & 64 & 78 & 12 & 22 & 60 & 69 & 4 & 12 & 176 & 145 & 2.7 & 3.0 & 2 & 5 \\
\hline 3. & $\begin{array}{l}\text { Inability of the organisation to cope with } \\
\text { threat and opportunity }\end{array}$ & 48 & 87 & 9 & 30 & 64 & 66 & 5 & 10 & 174 & 145 & 2.7 & 3.0 & 3 & 5 \\
\hline 4. & Low Productivity & 40 & 60 & 14 & 42 & 56 & 75 & 1 & 16 & 156 & 148 & 2.4 & 3.1 & 4 & 2 \\
\hline 5. & $\begin{array}{l}\text { Increase in cost of manpower } \\
\text { development }\end{array}$ & 44 & 81 & 11 & 32 & 64 & 66 & 2 & 16 & 82 & 148 & 1.3 & 3.1 & 7 & 2 \\
\hline 6. & High cost of production & 32 & 66 & 13 & 44 & 44 & 69 & 4 & 20 & 155 & 137 & 2.4 & 2.9 & 6 & 7 \\
\hline 7. & Low performance of organisation & 40 & 57 & 13 & 46 & 48 & 87 & 1 & 12 & 156 & 148 & 2.4 & 3.1 & 4 & 2 \\
\hline
\end{tabular}

Male $65 \quad$ Female 48

\section{APPENDIX VII}

Hyp. 1

$$
\begin{aligned}
& \text { Rho }=1-\frac{6 \Sigma d^{2}}{N\left(N^{2}-1\right)} \\
& 1-\frac{6(100)}{9\left(9^{2}-1\right)} \\
& 1-\frac{600}{9(81-1)} \\
& 1-\frac{600}{9(80)} \\
& 1-\frac{600}{720} \\
& 1-0.83=0.17 \\
& \begin{array}{lll}
\text { Rho } & \mathbf{0 . 1 7}
\end{array}
\end{aligned}
$$

Critical value at $\alpha=0.05=\mathbf{0 . 6 8 3 3}$
Hyp. 2

$$
\begin{aligned}
& \text { Rho }=1-\frac{6 \Sigma d^{2}}{N\left(N^{2}-1\right)} \\
& 1-\frac{6(47)}{7\left(7^{2}-1\right)} \\
& 1-\frac{282}{7(49-1)} \\
& 1-\frac{282}{7(48)} \\
& 1-\frac{282}{336} \\
& 1-0.84=0.16 \\
& \text { Rho }=0.16
\end{aligned}
$$

Critical value at $\alpha=0.05=\mathbf{0 . 7 4 5 0}$ 